\title{
Germination of native grasses with potential application in the recovery of degraded areas in Quadrilátero Ferrífero, Brazil
}

\author{
Maurílio Assis Figueiredo ${ }^{1,3}$, Hudson Eustáquio Baêta ${ }^{2}$ \& Alessandra Rodrigues Kozovits ${ }^{2}$ \\ ${ }^{1}$ Departamento de Geologia, Escola de Minas, Universidade Federal de Ouro Preto - UFOP, Campus \\ Universitário Morro do Cruzeiro, s/n, Bauxita, CEP 35400-000, Ouro Preto, MG, Brasil. www.ufop.br \\ ${ }^{2}$ Departamento de Biodiversidade Evolução e Meio Ambiente, Instituto de Ciências Exatas e Biológicas, \\ Universidade Federal de Ouro Preto - UFOP, Campus Universitário Morro do Cruzeiro, s/n, Bauxita, \\ CEP 35400-000, Ouro Preto, MG, Brasil. www.ufop.br \\ ${ }^{3}$ Corresponding author: Maurílio Assis Figueiredo, e-mail: maurilioafigueiredo@yahoo.com.br
}

FIGUEIREDO, M.A., BAÊTA, H.E. \& KOZOVITS, A.R. Germination of native grasses with potential application in the recovery of degraded areas in Quadrilátero Ferrífero, Brazil. Biota Neotrop. 12(3): http:// www.biotaneotropica.org.br/v12n3/en/abstract?article+bn02912032012

\begin{abstract}
Native grasses are potential species to be used in land rehabilitation. However, due to the lack of better knowledge of their performance, preference is given to exotic plants, which may be invasive and negatively affect the local biodiversity. In order to better understand the propagation of native species of the Quadrilátero Ferrífero (Minas Gerais, Brazil) using their seeds, and in so doing, indicate possible candidates for land rehabilitation, this study investigated the germination patterns of the following grasses: Andropogon bicornis L.; Andropogon leucostachyus Kunth; Setaria parviflora (Poir.) Kerguélen; Cenchrus brownii Roem. \& Schult; Echinolaena inflexa (Poir.) Chase, and Apochloa euprepes (Renvoize) Zuloaga \& Morrone. The spikelets (depending on the species, removing or not the structures that surround the caryopsis) were treated as follows: T1-Control, T2- moistening with $0.2 \%$ potassium nitrate, T3-heating at $80{ }^{\circ} \mathrm{C}$ for 2 minutes, T4- scarification with sulfuric acid (except genus Andropogon) and, for genera Andropogon and Setaria T5- storage at room temperature and T6- refrigerated storage. The treatment was repeated four times for 25 caryopses incubated at $25{ }^{\circ} \mathrm{C}$ and constant light. Significant variation was observed when comparing germination rates from week to week, treatment to treatment and species to species. The most efficient treatment for genus Andropogon was T6, followed by T2 for $A$. bicornis and T3 for $A$. leucostachyus. T6 was also the most effective treatment for $S$. parviflora, followed by T5 and T2. C. brownii showed similar results when applying T1, T2 and T3 (mean 39\%). E. inflexa and A. euprepes showed high levels of dormancy that were not overcome by the proposed treatments. A. bicornis, A. leucostachyus, S. parviflora and C. brownii showed higher germination potential, thus being possible candidates for the recovery of degraded areas. Future studies are indicated to find the most effective treatments for germination in field conditions.
\end{abstract}

Keywords: poaceae, seed dormancy, storage time, heating, potassium nitrate, caryopsis.

FIGUEIREDO, M.A., BAÊTA, H.E. \& KOZOVITS, A.R. Germinação de gramíneas nativas do Quadrilátero Ferrífero com potencial aplicação na recuperação de áreas degradadas. Biota Neotrop. 12(3): http://www. biotaneotropica.org.br/v12n3/pt/abstract?article+bn02912032012

Resumo: As gramíneas nativas apresentam potencial para revegetação de áreas degradadas, no entanto, devido ao pouco conhecimento sobre sua biologia, dá-se preferência ao uso de espécies exóticas, que podem ser invasoras, afetando assim a biodiversidade local. No intuito de ampliar o conhecimento acerca da propagação via sementes de espécies nativas do Quadrilátero Ferrífero (QF), e desta forma, indicar possíveis candidatas a aplicação na recuperação de áreas degradadas da região, este trabalho objetivou avaliar os padrões germinativos das seguintes gramíneas: Andropogon bicornis L.; Andropogon leucostachyus Kunth; Setaria parviflora (Poir.) Kerguélen, Cenchrus brownii Roem. \& Schult; Echinolaena inflexa (Poir.). Chase e Apochloa euprepes (Renvoize) Zuloaga \& Morrone. As espiguetas (com presença ou não das estruturas que envolviam a cariopse, dependendo da espécie) foram submetidas aos seguintes tratamentos: T1-controle; T2- umedecimento do substrato com $0,2 \%$ de nitrato de potássio, T3- aquecimento a $80^{\circ} \mathrm{C}$ por 2 minutos, T4- escarificação com ácido sulfúrico (exceto gênero Andropogon) e para os gêneros Andropogon e Setaria, T5- armazenamento a temperatura ambiente e T6armazenamento sob refrigeração. Os tratamentos foram realizados em 4 repetições de 25 cariopses colocadas para germinar a temperatura de $25^{\circ} \mathrm{C}$ e iluminação constante. Variação significativa foi observada quando comparadas as quantidades de germinações ocorridas entre as semanas, entre os tratamentos e entre as espécies. Para o gênero Andropogon o tratamento mais eficiente foi T6, seguido por T2 em A. bicornis e T3 em A. leucostachyus. T6 também foi o tratamento mais eficiente para $S$. parviflora, seguido por T5 e T2. C. brownii apresentou resultados próximos sob T1, T2 e T3 (média 39\%). E. inflexa e A. euprepes apresentaram altos índices de dormência que não foram superadas pelos tratamentos propostos. A. bicornis, A. leucostachyus, S. parviflora e C. brownii apresentaram maiores potenciais de germinação, sendo possíveis candidatas para recuperação de áreas degradas no QF. No entanto, ainda são necessários estudos complementares com os tratamentos mais eficientes e testes de germinação e estabelecimento em condições de campo.

Palavras-chave: poaceae, dormência de sementes, tempo de armazenamento, aquecimento, nitrato de potássio, cariopse. 


\section{Introduction}

The Quadrilátero Ferrífero, located in the southern portion of the Espinhaço Range, is one of the richest areas in biodiversity and endemic species of the Minas Gerais State (Brazil), and should receive priority attention when it comes to conservation (Drummond et al. 2005). The region has also received much attention for its contribution to the country's economy, accounting for approximately $70 \%$ of the Brazilian iron ore production (Brasil 2011), which is the second largest of the world (Instituto... 2011). To reconcile these two important aspects and in order to minimize the impacts of mining on local biodiversity, among other actions, recovery projects in degraded areas should prioritize the restoration of natural environment conditions and use native species (Gardner 2001).

Unfortunately, the knowledge on the tolerance of certain plants to the extreme conditions found in abandoned mining areas is restricted to a few exotic species (Ginocchio \& Baker 2004). African grasses are a group of exotic plants most used for recovery of degraded areas in Brazil. Here, they have found soil and climate conditions similar to or more favorable than those of their original habitat, thus causing them to develop faster than the native species (Freitas \& Pivello 2005).

The attributes that make exotic grasses efficient in recovering unprotected soil are probably the same as those that make them better competitors than native species. According to Freitas \& Pivello (2005), the establishment and spreading of plant species from other regions in natural or managed ecosystems can reduce, extinguish and misbalance populations of original flora and thus alter the ecosystem equilibrium, which is today one of the worst environmental problems.

The substitution of exotic by native species in soil recovery projects has already attracted the interest of some mining companies. However, the ignorance regarding botany and ways of propagation of native species on the different areas of Brazil is no doubt the most impeding factor for the development of satisfactory recovery practices (Negreiros et al. 2002). With respect to native grasses, in fact, management is still difficult because studies are lacking (Filgueiras \& Fagg 2008).

Jacobi et al. (2008) and Filgueiras \& Fagg (2008) highlighted the potential of some native grasses as pioneer vegetation in the recovery of degraded areas. According to Filgueiras \& Fagg (2008), native grasses such as Andropogon bicornis L., A. leucostachyus Kunth, Echinolaena inflexa (Poir.) Chase and Setaria parviflora (Poir.) Kerguelen among others, present morphological and physiological characteristics that enable them to survive in harsh environments, thus making them good candidates for land rehabilitation. In addition to these species, we can also mention Apochloa euprepes (Renvoize) Morrone \& Zuloaga, a native grass (Filgueiras et al. 2010) with high importance value index in some grasslands developing on rocky (quartzite) outcrops in the Itacolomi State Park and the Ouro Branco range, where some soil features (Lemes 2009) and microclimatic conditions may have selected adaptations that made such plants potential candidates for application in the recovery of degraded areas. Cenchrus brownii Roem \& Schult is a native grass (Filgueiras et al. 2010) with wide distribution in Central and South America (Clayton et al. 2010), showing good spreading capacity in disturbed environments.

In this study we investigated the germination patterns of species widely distributed in the Quadrilatero Ferrífero: A. bicornis, A. leucostachyus, Apochloa euprepes, C. brownii, E. inflexa and $S$. parviflora, so as to establish a basis for future studies focusing on the use of these native grasses in programs of biodiversity preservation in rocky regions and in the recovery of degraded areas.

\section{Materials and Methods}

Most of the spikelets were collected in the municipalities of Ouro Preto and Mariana (Minas Gerais), from January to March 2010.
C. brownii spikelets, in particular, were collected in July 2009. The spikelets of several individuals (more than 30 per species) within a population were randomly sampled, excepting $E$. inflexa, because the propagation through rhizomes does not allow the distinction of individual plants. The spikelets were collected manually from branches that had started natural release of spikelets. Immediately after harvest, they were dried in the shade at room temperature. The spikelets that were not used in germination tests were divided into two sets immediately after drying. These were stored at (1) room temperature in paper bags or (2) in paper bags wrapped in plastic bags and stored under refrigeration at about $8{ }^{\circ} \mathrm{C}$ (Salomão 2003).

Specimens in the reproductive period were collected, identified by experts and deposited in the Professor José Badini Herbarium collection (Herbarium OUPR) of the Universidade Federal de Ouro Preto (UFOP).

Andropogon spikelets were selected for the removal of impurities with no distinction between empty and full spikelets. Due to their small size, differences between full and empty spikelets are minimal, thus making the manual selection very slow, as also reported by Carmona et al. (1999). The Andropogon spikelets were tested without the removal of any structure surrounding the caryopsis. The structures surrounding the caryopsis of E. inflexa and Apochloa euprepes were removed by rubbing a small amount of spikelets on the palm of one hand with the thumb of the other. This mixture of caryopses and straw was homogenized in a $1000 \mathrm{~mL}$ beaker containing water. A few seconds after homogenization, the supernatant material was discarded and the caryopses at the bottom of the beaker were collected after pouring the beaker's content through a sieve. For preliminary analysis, two groups of caryopsis with different densities were sectioned and the presence of endosperm was observed under the magnifying glass. All caryopses collected from the bottom of the beaker presented endosperm, whereas the floating material did not. Immediately after this selection, caryopses were taken to germinate.

Filled spikelets of $S$. parviflora were separated from the empty ones by applying a light pressure with a clamp on each spikelet. The filled ones were resistant to pressure. In C. brownii the structures surrounding the caryopses were removed, and the selection of full/ empty caryopses was visually possible. For simplicity, from now on both caryopses and spikelets will be referred to as seeds.

\section{Germination Tests}

Germination tests were performed in the UFOP Laboratory of Plant Ecophysiology. Each test consisted of four petri dishes, where 25 seeds were placed to germinate on two sheets of filter paper. In each plate, $4 \mathrm{~mL}$ Nystatin (1000 IU/L) were added (Oliveira \& Garcia 2005 ) to promote seed hydration and reduce fungal contamination. The petri dishes were sealed with tape to avoid moisture loss and placed in a germination chamber at $25{ }^{\circ} \mathrm{C}$ under continuous illumination. The position of the plates inside the chamber was randomly changed every 24 hours.

In order to reduce contamination by microorganisms, especially fungi, all pieces of glassware used for seed germination were previously immersed in a solution of hydrochloric acid (HCL) $1 \%$ for thirty minutes and then rinsed three times with distilled water and dried in an oven at $100{ }^{\circ} \mathrm{C}$.

\section{Treatment}

Seeds were treated as follows:

Control (T1) - germination in the presence of light and hydration with Nystatin solution.

Potassium nitrate (T2) - hydrated germination with a solution of potassium nitrate $\left(\mathrm{KNO}_{3}\right) 0.2 \%$. 
Pre-heating (T3) - Seeds were placed in an oven for two minutes at $80{ }^{\circ} \mathrm{C}$ and then transferred to the germination chamber.

Scarification with sulfuric acid (T4) - seeds were soaked in sulfuric acid $\left(\mathrm{H}_{2} \mathrm{SO}_{4}\right)$ for three minutes and then washed in running water to avoid contamination of the embryo and then transferred to the germination chamber. This treatment was not applied to Andropogon seeds because, due to their small size, immersion in acid could destroy them.

Storage - A. bicornis, A. leucostachyus and S. parviflora seeds were also tested for the effects of storage on germination rate. The seeds were stored at room temperature (T5) or refrigerated (T6) to about $8{ }^{\circ} \mathrm{C}$ for eight months and then taken to the germination chamber.

Germination was evaluated daily. Seeds with at least a 2-3 mm radicle and / or coleoptile were considered germinated, counted and taken from the plates. The experiments were finished seven days after the last germination. The statistical analysis involved Generalized Linear Models (GLM) with quasi-binomial error distribution. The germination time, kind of treatment and species were established as fixed parameters, as well as the interaction between this fixed parameters. GLM was chosen because of the binomial nature of the data and was applied by means of the free software R (R Development Core Team 2011).

\section{Results}

Table 1 shows the variations observed in the germination percentages from week to week (week), treatment to treatment (trat) and species (sp.). It also shows the variations observed among treatments in each week (week: trat), among species in each week (week: sp), and among treatments in each species (trat: sp).

The most effective treatments in overcoming dormancy of Andropogon bicornis seeds were refrigerated storage (28\%) and germination in treatment with $\mathrm{KNO}_{3}$ solution $(24 \%)$. These treatments produced much better results than treatment control $(18 \%)$, whereas the other treatments led to germination rates lower than treatment control (Figure 1a). It took a maximum of 27 days for A. bicornis to germinate, with a notable difference in the distribution of germination rates among the treatments during this period. Most treatments promoted higher percentage of germination in the first week (Figure 1a), specially the pre-heating, in which about $86 \%$ of the total germination occurred in the first seven days. Despite germination was accelerated by pre-heating, the total number of seed germination was not favored.

Although they belong to the same genus and are sympatric, the germination patterns of A. leucostachyus and A. bicornis were not similar. The best Andropogon leucostachyus germination occurred after storing under refrigeration $(58 \%)$, whereas the worst results

Table 1. Results of statistical analysis using generalized linear models with distribution of errors quasibinomiais for period of observation, treatments and species.

Tabela 1. Resultados da análise estatística utilizando modelos lineares generalizados com distribuição de erros quasibinomiais para período de observação, tratamentos e espécies.

\begin{tabular}{lcrc}
\hline \multicolumn{1}{c}{ Factor } & Df & \multicolumn{1}{c}{ F } & Significant \\
\hline Time & 1 & 343,33 & $\mathrm{p}<0,01$ \\
Tratament & 5 & 13,76 & $\mathrm{p}<0,01$ \\
Species & 5 & 56,52 & $\mathrm{p}<0,01$ \\
Time:tratament & 5 & 2,61 & $\mathrm{p}=0,03$ \\
Time:species & 5 & 25,02 & $\mathrm{p}<0,01$ \\
Specie:tratament & 17 & 2,48 & $\mathrm{p}<0,01$ \\
\hline
\end{tabular}

occurred after storing Andropogon leucostachyus seeds at room temperature $(11 \%)$. The second most effective treatment was pre-heating, which resulted in $51 \%$ germination. In average, $37 \%$ germination occurred after the other treatments were applied to the seeds (Figure 1b).

In general, A. leucostachyus germination occurred in 17 days. Except for the treatment of storage at room temperature, more than $90 \%$ germination happen for all the other treatments in the first seven days (Figure 1b).

S. parviflora germination was much higher than treatment control $(11 \%)$ after the following three treatments: storage under refrigeration $(29 \%)$, storage at room temperature $(27 \%)$ and germination in $\mathrm{KNO}_{3}$ solution $(25 \%)$. The pre-heating values were slightly higher than control, while scarification in sulfuric acid promoted germination rates lower than treatment control (Figure 1c).

It took a maximum of 19 days for S. parviflora to germinate, with most of the germination concentrated in the first week. Germination was the fastest after storage under refrigeration, completely occurring in the first seven days of testing (Figure 1c).

The treatments assessed were inefficient or promoted only low germination rates (less than 5\%) for E. inflexa in two treatments and $1 \%$ for $A$. euprepes in the $\mathrm{KNO}_{3}$ treatment (Figure 1e, $\mathrm{f}$ ).

With the exception of scarification with sulfuric acid, the other treatments promoted an average of $39 \%$ germination of Cenchrus brownii (Figure 1d). It took a maximum of 28 days for $C$. brownii to germinate. Treatment with $\mathrm{KNO}_{3}$ promoted the highest germination percentage $(42 \%)$, which was concentrated in the first week, while other treatments led to higher germination in the second week of the experiment (Figure 1d).

\section{Discussion}

As a whole, the results showed that the studied species, even if native of a relative small area, responded very differently to the proposed treatments. This reinforces the need for more specific work on each species in order to identify better germination conditions.

The germination rates found for the A. bicornis seeds in the two most effective treatments were similar to those obtained by Carmona et al. (1998), who worked with seeds collected in the Federal District, which were previously mechanically selected and stored for six months at room temperature. The authors obtained a germination percentage of $27 \%$. However, it is important to note that in the present study, seeds were not pre-selected or pre-prepared as in Carmona et al. (1999), suggesting that refrigerated storage and germination in $\mathrm{KNO}_{3}$ solution were more efficient in promoting $A$. bicornis germination than the treatments applied by these authors.

According to Carmona et al. (1999), the percentage of full seeds in A. bicornis is only about $35 \%$ of the total seed set. Taking it as a reference, hypothetically, the storage under refrigeration for 8 months would promote about $80 \%$ germination of the viable seeds in the present study.

Despite pre-heating of $A$. bicornis only accelerated the germination process, the results of this treatment applied to A. leucostachyus were better in terms of total number of germination. The enhancement of germination rates in treatments that simulate the effects of fire events is expected for native species of seasonal environments, where fires occur naturally. The stimulation of germination after fire may be a result of evolutionary adaptation. After burning, more nutrients are available, competition with other plants is less intense and herbivores are less menacing (Lamont et al. 1993, Tyler 1995), which can facilitate the establishment of seedlings that have germinated just after fire. Temperatures between $80^{\circ} \mathrm{C}$ and $100{ }^{\circ} \mathrm{C}$ at $0.3-\mathrm{cm}$ and $1-\mathrm{cm}$ depth in topsoil have been observed in 

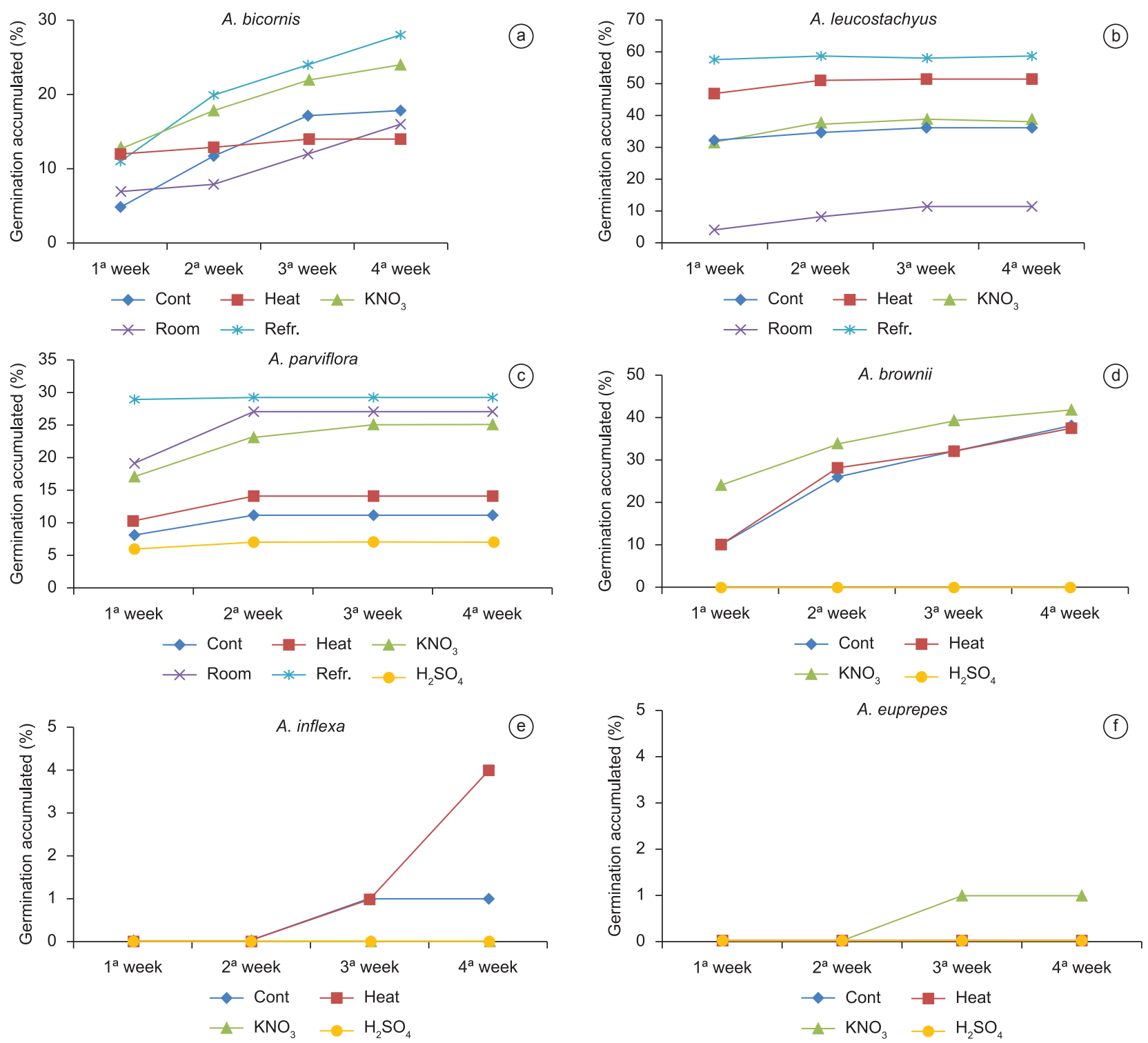

Figure 1. Accumulated percentage of germination after different treatments, under $25^{\circ} \mathrm{C}$ and continuous illumination. (a) Andropogon bicornis; (b) Andropogon leucostachyus; (c) Setaria parviflora; (d) Cenchrus brownii; (e) Echinolaena inflexa; (f) Apochloa euprepes. Cont - control; Heat- heating; $\mathrm{KNO}_{3}$ - potassium nitrate; $\mathrm{H}_{2} \mathrm{SO}_{4}$ - sulfuric acid; Room - storage room temperature; Refr - storage refrigerate temperature. (Note different scales for axis $\mathrm{Y}$ ).

Figura 1. Porcentagem de germinação acumulada das gramíneas avaliadas em diferentes tratamentos à temperatura de $25^{\circ} \mathrm{C}$ e iluminação continua. (a) Andropogon bicornis, (b) Andropogon leucostachyus (c) Setaria parviflora; (d) Cenchrus brownii; (e) Echinolaena inflexa; (f) Apochloa euprepes. Cont - controle; Heat- pré- aquecimento; $\mathrm{KNO}_{3}$ nitrato de potássio; $\mathrm{H}_{2} \mathrm{SO}_{4}$ - Ácido sulfúrico; Room- Armazenamento a temperatura ambiente; Refr- Armazenamento sob refrigeração. (Notar que as escalas do eixo Y são diferentes).

seasonal savanna environments during fire events, which is the same temperature used in the present study and that caused germination rates to increase. Temperatures above $120{ }^{\circ} \mathrm{C}$, however, seemed to be lethal to seeds (Williams et al. 2003, 2004).

The highest $A$. leucostachyus germination rates observed in the present study were close to the best germination rates obtained by Giotto (2010), who performed tests at alternating temperatures of 20-35 ${ }^{\circ} \mathrm{C}$ and during a 12-hour photoperiod. The author obtained $59 \%$ germination in a solution of potassium nitrate and by removing the structures surrounding the caryopsis. However, when working with seeds stored for 10 months, at room temperature or at $4{ }^{\circ} \mathrm{C}$, she obtained much lower germination rates of $6 \%$ and $28 \%$, respectively. Dissimilarities between the results obtained by us and by Giotto (2010) may be related to differences in both temperature and luminosity applied, besides the period and the temperature of storage. Adaptations of the two A. leucostachyus populations to climatic conditions may also differ, since the study regions where the seeds were collected are about $800 \mathrm{~km}$ distant from each other. However, it is clear that pre-heating and refrigerated storage as proposed in our study are the most suitable treatments to overcome A. leucostachyus seed dormancy.

The interference caused by temperature in A. leucostachyus germination suggests the need for more detailed studies. Different temperature variations should be tested in future studies in order to find the best germination conditions, including also pre-cooling treatments, as proposed for some species of the same genus (Brasil 2009). Another A. leucostachyus germination behavior also evidenced by Giotto (2010) is its low response in $\mathrm{KNO}_{3}$ solution, 
which is uncommon for some species of the genus (Brasil 2009). The A. leucostachyus population sampled in our study occupies organic matter-free environments, which may have unfavorably alter their germination pattern in the presence of nitrate. According to Carmona et al. (1997), Gymnopogon Doellii Boechat \& Valls, a native savanna grass, tend to respond positively to $\mathrm{KNO}_{3}$ because this treatment simulates part of the optimal conditions for species germination under field conditions where organic matter is decomposing.

The fact that germination rates of Andropogon seeds were higher after storage for eight months under refrigeration may indicate that dormancy in this species can be overcome by aging, as has been observed in other species of the same genus (Eira 1983) and in other grasses (Carmona et al. 1998, Giotto 2010). On the other hand, storage at room temperature reduced germination rate, suggesting that storage under refrigeration allows the overcoming of dormancy (Brasil 2009) and reduces the degradation process. According to Peterbauer \& Richter (2001), storage at low temperatures may reduce the enzymatic activity, better preserving the cellular components.

The dormancy of $S$. parviflora seeds seemed to be sensitive to storage or $\mathrm{KNO}_{3}$, but the germination percentages obtained with both treatments were still low, considering that all the seeds were filled. Perhaps the storage for a longer time interval or a combination of storage and use of $\mathrm{KNO}_{3}$ can contribute to higher germination percentages than those obtained in the present work. Another treatment with potential to enhance $S$. parviflora germination rates is the removal of structures surrounding the caryopsis. Working with Setaria poirentiana (Schult.) Kunth, a native grass, Giotto (2010) observed that this treatment caused a large increase in the number of germinations. The dormancy of $S$. parviflora seeds was sensitive to storage, a feature that contrasts with the results found for native grasses of the same genus (Carmona et al. 1998, Giotto 2010). Since $S$. parviflora seed size is big enough, in future studies tests should be applied in order to define the real number of viable seeds, as has been proposed for the genus by Brasil (2009).

Despite the low E. inflexa germination percentages obtained in the present study, another study found $90 \%$ of seed viability (Silva \& Rocha Filho 1991). Klink (1993) tested seeds stored for six months under a constant temperature of $25^{\circ} \mathrm{C}$ and using soil as substrate. This author obtained $30 \%$ germination, which started from the seventh day of the experiment and was much earlier than that observed in the present study. Apparently, the overcoming of $E$. inflexa seed dormancy should also be favored by storing, as proposed by Giotto (2010). The author also suggested the removal of structures surrounding the caryopsis in association with germination under alternated temperature of $20-35^{\circ} \mathrm{C}$ and a 12 -hour photoperiod, which can be positive in overcoming E. inflexa dormancy. A good alternative to restrictions on sexual propagation of E. inflexa is to improve its spreading with vegetative material (rhizomes), as has successfully been done by Miranda (2009) and Marques et al. (2010).

Despite high seed production and large number of filled seeds (our observations), Apochloa euprepes germination percentages were not satisfactory enough to recommend this species for recovery of degraded areas. Apochloa euprepes seeds did not respond to any of the treatments, suggesting that the overcome of dormancy may be enhanced by aging. Another factor that might be linked to the interruption of $A$. euprepes dormancy is fire, since the species is commonly found in rocky fields in dense mats. The pre-heating treatment proposed here, however, did not stimulate germination, probably because it did not simulate all the changes promoted by fire in natural environments, such as smoke, for example (Keith 1997, Fidelis et al. 2007).
In experiments with Cenchrus echinatus L., Martins et al. (1997) obtained similar results to those found for C. brownii in the present work, where no germination was observed in $\mathrm{H}_{2} \mathrm{SO}_{4}$ treatment, but in $\mathrm{KNO}_{3}$. The authors found higher Cenchrus echinatus germination rates after removal of the casing bracts and glumes. Further experiments should be conducted with $C$. brownii in order to check whether removal of these parts will facilitate germination. Such a procedure is time-consuming, which may be a major impediment to large-scale C. brownii spreading.

\section{Conclusions}

Seeds of all the species studied here presented some kind of dormancy. A. bicornis, A. leucostachyus, S. parviflora and C. brownii were sensitive to, at least, one of the treatments proposed. Refrigerated storage of Andropogon and S. parviflora for eight months was the most efficient treatment to overcome dormancy. Storage at room temperature of $S$. parviflora also produced good results. The preheating treatment stimulated A. leucostachyus germination and interfered in the time of $A$. bicornis germination, whereas scarification with $\mathrm{H}_{2} \mathrm{SO}_{4}$, as applied in this work, was detrimental to germination of all species. The use of $\mathrm{KNO}_{3}$ was the most suitable treatment for A. bicornis, S. parviflora and C. brownii germination immediately after harvest. In contrast, this treatment caused no positive effect in A. leucostachyus germination.

A. bicornis, A. leucostachyus and S. parviflora, besides their morphological and physiological characteristics that make them suitable for the recovery of degraded areas, also presented good germination rates under laboratory conditions.

\section{Acknowledgements}

The authors thank the staff of the Herbarium Prof. José Badini for preparation of plant material, Pedro Viana (UFMG) for help in identifying some grasses and IEF for allowing collections in PEIT. The study was supported by grants from FAPEMIG (Pesquisador Mineiro 2009) and CNPq (No 577323/2008-3). Maurilio A. Figueiredo was supported by UFOP-fellowship.

\section{References}

BRASIL. Ministério da Agricultura, Pecuária e Abastecimento. 2009. Regras para análise de sementes. MAPA/ACS, Brasília.

BRASIL. Ministério de Minas e Energia. 2011. Sumário Mineral. Ministério de Minas e Energia. Departamento Nacional de Produção Mineral. DNPM/ DIPLAM, Brasília.

CARMONA, R., CAMILO, M.G.B. \& MARTINS, C.R. 1997. Estimulo à germinação em sementes de Gymnopogon doellii uma gramínea ameaçada de extinção. Rev. bras. fisiol. veg. 9:125-130.

CARMONA, R., MARTINS, C.R. \& FÁVERO, A.P. 1999. Características de sementes de gramíneas nativas do cerrado. Pesqui. agropecu. bras. 34:1067-1074.

CARMONA, R., MARTINS, C.R. \& FÁVERO, A.P. 1998. Fatores que afetam a germinação de sementes de gramíneas nativas do cerrado. Rev. bras. sementes. 20:16-22.

CLAYTON, W.D., HARMAN, K.T. \& WILLIAMSON, H. 2010. Grass Base: The Online World Grass Flora. http://www.kew.org/data/grasses-db/www/ imp02038.htm (último acesso 17 ago 2010).

DRUMMOND, G.M., MARTINS, C.S., MACHADO, A.B.M., SEBAIO, F.A. \& ANTONINI, Y. (Org.). 2005. Biodiversidade em Minas Gerais: um Atlas para sua conservação. Fundação Biodiversitas, Belo Horizonte.

EIRA, T.S. 1983. Comparação de métodos de quebra de dormência em sementes de capim Andropogon. Rev. bras. sementes. 5:37-49. 
FIDELIS, A., MÜLLER, S.C., PILLAR, V.D. \& PFDENHAUER, J. 2007. Efeito de Altas Temperaturas na Germinação de Espécies dos Campos Sulinos. Rev. bras. biociênc. 5:354-356.

FILGUEIRAS, T.S. \& FAGG, C.W. 2008. Gramíneas nativas para a recuperação de áreas degradadas no cerrado. In: Bases para a recuperação de áreas degradadas na Bacia do São Francisco (FELFILI, J.M., SAMPAIO, J.C. \& CORREIA, C.R.M. de A., ed.). Centro de Referência em Conservação da Natureza e Recuperação de Áreas Degradadas (CRAD), Brasília, p.89-108.

FILGUEIRAS, T.S., LONGHI-WAGNER, H.M., VIANA, P.L., ZANIN, A., GUGLIERI, A., OLIVEIRA, R.C. de, CANTO-DOROW, T.S., SHIRASUNA, R.T., VALLS, J.F.M., OLIVEIRA, R.P., RODRIGUES, R.S., SANTOS-GONÇALVES, A.P. \& WELKER, C.A.D. 2012. Poaceae in Lista de Espécies da Flora do Brasil. Jardim Botânico do Rio de Janeiro. http://floradobrasil.jbrj.gov.br/2012/FB000193. (último acesso 06 jul 2012)

FREITAS, G.K. \& PIVELLO, V.R. 2005. A ameaça das gramíneas exóticas a biodiversidade. In. O cerrado Pé-de-Gigante: ecologia e conservação - Parque Estadual de Vassununga.(PIVELLO, V.R.; VARANDA, E.M., ed.) SMA, São Paulo, p. 233-348.

GARDNER, J. 2001. Rehabilitación de minas para el mejor uso del terreno:la minería de bauxita en el bosque de jarrah de Australia Occidental. Unasylva. 52:3-8

GINOCCHIO, R. \& BAKER, A.J.M. 2004. Metallophytes in Latin America: a remarkable biological and genetic resource scarcely known and studied in the region. Rev. chil. hist. nat. 77:185-194. http://dx.doi.org/10.4067/ S0716-078X2004000100014

GIOTTO, A.C. 2010. Avaliação do desenvolvimento dos componentes arbóreos e herbáceos na recuperação de áreas degradadas na Bacia do Ribeirão do Gama, Distrito Federal. Dissertação de mestrado, Universidade de Brasília, Brasília.

Instituto Brasileiro de Mineração - IBRAM. 2011. Informações e análises da economia mineral brasileira. 7.ed. IBRAM, Brasília.

JACOBI, C.M., CARMO, F.F. \& VINCENT, R.C. 2008. Estudo fitossociológico de uma comunidade vegetal sobre canga como subsídio para a reabilitação de áreas mineradas no Quadrilátero Ferrífero, MG. Rev. arvore. 32:345-353 http://dx.doi.org/10.1590/S010067622008000200017

KEITH, D.A.1997. Combined effects of heat shock, smoke and darkness on germination of Epacris stuartii Stapf., an endangered fire-prone Australian shrub. Oecologia. 112:340-344. http://dx.doi.org/10.1007/ s004420050318

KLINK, C.A. 1993. Germination and seedling establishment of two native and one invading African Grass species in the Brazilian Cerrado. Journal of tropical Ecology. 12:139-147. http://dx.doi.org/10.1017/ S0266467400009354

LAMONT, B.B., WITKOWSKI, E.T.F. \& ENRIGHT, E.J. 1993. Post-fire litter microsites: safe for seeds, unsafe for seedlings. Ecology. 74:501-512. http://dx.doi.org/10.2307/1939311
LEMES, F.O.A. 2009. Relações florísticas, fitossociológicas e aspectos edáficos de comunidades de campos rupestres da Serra do Itacolomi e Serra do Ouro Branco, Minas Gerais. Dissertação Mestrado. Universidade Federal de Ouro Preto, Ouro Preto.

MARQUES, T.E.D., ALVES, L.R., ALMEIDA, E.F., BAÊTA, H.E., LEITE, M.G.P. \& KOZOVITS, A.R. 2010. Uso de gramíneas em consórcio com leguminosa para a recuperação de voçoroca. In VIII Simpósio Nacional sobre Recuperação de Áreas Degradadas (M. Balensiefer, coord). Sobrade, Curitiba, p. 451-464.

MARTINS, C.C., VELINI, E.D. \& MARTINS, D. 1997.Superação da dormência de sementes de capim-carrapicho. Planta daninha. 15:61-71.

MIRANDA, V.T. 2009. Competitividade de espécies arbóreas juvenis e gramíneas do cerrado e suas respostas ao aumento da disponibilidade de nitrogênio. Dissertação Mestrado. Universidade Federal de Ouro Preto, Ouro Preto.

NEGREIROS, D., SILVEIRA, F.A.O., RANIERI, B.D., LANA, T.C., LIMA, L.G., ARAÚJO, L.M., OLANDIM, L., SILVA, C.A. \& FERNANDES, G.W. 2002. Recuperação de áreas degradadas em solos quartzíticos com espécies nativas. http://www.agencia.cnptia.embrapa.br/recursos/SL . (último acesso 18 maio 2010).

OLIVEIRA, P.G. \& GARCIA, Q.S. 2005. Efeitos da luz e da temperatura na germinação de sementes de Syngonanthus elegantulus Ruhland, S. elegans (Bong.) Ruhland e S. venustus Silveira (Eriocaulaceae). Acta bot. bras. 19:639-645.

PETERBAUER, T. \& RICHTER, A. 2001. Biochemistry and physiology of raffinose family oligosaccharides and galactosyl cyclitols in seeds. Seed Science Research. 11:185-197.

R DEVELOPMENT CORE TEAM 2011. R: A language and environment for statistical computing. R Foundation for Statistical Computing, Vienna, Austria. Disponível em: http://www.R-project.org/. (último acesso 17 jul 2010)

SALOMÃO, A.N. \& SILVA, J.C.S. 2003. Germinação análise e armazenamento de sementes. In Germinação de sementes e produção de mudas de plantas do cerrado (SALOMÃO, A.N., ed.). Rede de Sementes do Cerrado, Brasília. p.3-8.

SILVA, J.C.S. \& ROCHA FILHO, G.A. 1991. Fisiologia da germinação de espécies dos cerrados com potencial forrageiro. In Relatório técnico anual do centro de pesquisa agropecuária dos cerrados (EMBRAPA/ CPAC, ed.). EMBRAPA, Brasília.

TYLER, C.M. 1995. Factors contributing to post?re seedling establishment in chaparral: direct and indirect effects of ?re. The Journal of Ecology. 83:1009-1020. http://dx.doi.org/10.2307/2261182

WILLIAMS, P.R., CONGDON, R.A., GRICE, A.C. \& CLARKE, P.J. 2003. Fire-related cues break seed dormancy of six legumes of tropical eucalypt savannas in north-eastern Australia. Austral Ecology. 28:07-514.

WILLIAMS, P.R., CONGDON, R.A., GRICE, A.C. \& CLARKE, P.J. 2004. Soil temperature and depth of legume germination during early and late dry season fires in a tropical eucalypt savanna of north-eastern Australia. Austral Ecology. 29:258-263. 